\title{
GAME SIMULASI BELAJAR PEMBAGIAN BERBASIS MULTIMEDIA UNTUK ANAK KELAS 5
}

\author{
I Ketut Sudaryana ${ }^{1}$, Rouly Doharma ${ }^{2}$ \\ Program Studi Teknik Informatika ${ }^{1}$, Sistem Informasi ${ }^{2}$, STMIK Widuri Jakarta, Indonesia \\ E-mail : Ketutbali2010@gmail.com ${ }^{1}$,rouly.doharma@gmail.com ${ }^{2}$
}

Submission date : 2020-05-02

Accepted date: 2020-05-10

\begin{abstract}
Learning to count for school children becomes a daunting subject matter, difficult because it requires thinking and using reasoning to solve it. As material that has been taught since elementary school, media are needed that can help students learn to count. To overcome students' difficulties in learning to count, Diginusa has special counting software for grade 5 children, based on multimedia that combines elements of text, sound, images and animation. The purpose of this study is to make learning to count easier because it is done in the form of a visualization on a computer monitor screen. This research utilizes quantitative data types, with data collection obtained from the results of software experiments to students in the form of grades that will be compared with the KKM scores. The Tecknology Acceptance Model (TAM) application is used to measure acceptance of interactive learning media. This TAM model illustrates the acceptance of the use of information technology that is strongly influenced by usefulness. The results of this study are from two data that are processed based on Minimum Completeness Criteria (KKM) whose percentage is $97 \%$ and the results of the Questionnaire are 64\%.
\end{abstract}

Keywords: Software, Multimedia, Interactive, TAM.

\begin{abstract}
ABSTRAK
Belajar berhitung bagi anak-anak sekolah menjadi materi pelajaran yang menakutkan, sulit karena membutuhkan pemikiran dan penggunaan nalar dalam menyelesaikannya. Sebagai materi yang sudah di ajarkan sejak sekolah dasar, maka dibutuhkan media yang mampu membantu anak didik dalam belajar berhitung. Untuk mengatasi kesulitan siswa dalam belajar berhitung, Diginusa memiliki software khusus berhitung untuk anak kelas 5, berbasis multimedia yang menggabungkan unsur teks, suara, gambar dan animasi. Tujuan dari penelitian ini agar belajar berhitung menjadi lebih mudah karena dilakukan dalam bentuk visualisi di layar monitor komputer. Penelitan ini memanfaatkan jenis data kuantitatif, dengan pengumpulan data diperoleh dari hasil eksperiman software kepada siswa berupa nilai yang nantinya akan dibandingkan dengan nilai KKM. Aplikasi Tecknology Acceptance Model (TAM) digunakan untuk mengukur penerimaan media pembelajaran interaktif. Model TAM ini menggambarkan penerimaan penggunaan teknologi informasi yang sangat dipengaruhi oleh kemanfaatan (usefulness). Hasil dari penelitian ini ialah dari dua data yang diolah berdasarkan Kriteria Ketuntasan Minimal (KKM) yang prosentasenya berada pada $97 \%$ dan hasil dari Kuesioner berada pada hasil $64 \%$.
\end{abstract}

Kata Kunci: Perangkat Lunak, Multimedia, Interaktif, TAM

\section{PENDAHULUAN}

Berhitung menjadi materi yang ditakuti dan menjadi momok bagi siswa sekolah, karena berhitung membutuhkan penalaran dan pemahaman, sehingga berhitung menjadi materi yang sulit. Oleh sebab itu dibutuhkan media pembelajaran yang mampu membantu siswa dalam memahami materi berhitung. Ada banyak hal yang dapat mempengaruhi proses belajar siswa sekolah dasar diantaranya guru, murid, kepala sekolah dan bahan ajar atau media pembelajaran. Media memiliki pengertian sebagai alat bantu, dengan demikian media pembelajaran merupakan perangkat lunak yang difungsikan sebagai alat bantu pada proses pembelajaran berhitung. Diginusa Jakarta yang bergerak dalam bidang pendidikan computer (TIK) untuk sekolah dasar membuat perangkat lunak (software) khusus untuk membantu siswa kelas 5 belajar berhitung (Arsyad, 2009). 
Game edukasi adalah permainan yang bertujuan untuk memancing minat belajar anak terhadap materi pelajaran sambil bermain, sehingga dengan perasaan senang diharapkan anak bisa lebih mudah memahami materi pelajaran yang disajikan.

Game edukasi merupakan salah satu tema permainan yang berusaha memberikan nilai edukasi dalam sebuah permainan, sehingga permainan yang awalnya hanya berfungsi sebagai media penghibur, akhirnya juga dapat digunakan sebagai media pembelajaran atau pelatihan (Kuswardayan,I, Nikensasi, P, 2012).

Penelitian dari Dony Novaliendry dengan judul Aplikasi Game Geografi Berbasis Multimedia Interaktif (Studi Kasus Siswa Kelas Ix SMPN 1 Rao). Media pembelajaran dirancang dengan menggunakan game edukasi berbasis multimedia interaktif, di mana minat siswa untuk belajar tidak hanya dari kursus multimedia, tetapi juga berinteraksi dengan bermain game pendidikan yang dirancang. Dalam penelitian ini, sebuah aplikasi Geografi dirancang berdasarkan pelajaran yang terkait dengan permukaan bumi atau proses pembelajaran dari studi geografi regionalisasi daerah bumi dalam bentuk peta pengetahuan dan negara. Permainan berarti bahwa lebih banyak siswa dapat meningkatkan kreativitas mereka dan memperkenalkan tentang teknologi komputer (Dony Novaliendry, 2013).

Penelitian dari Ratih Wulandari, Herawati Susilo, dan Dedi Kuswandi dengan judul Multimedia Interaktif Bermuatan Game Edukasi Sebagai Salah Satu Alternatif Pembelajaran IPA di Sekolah Dasar. Penggunaan media dalam pembelajaran bertujuan untuk mempermudah guru dalam menyampaikan materi dan siswa lebih memahami yang di- pelajari. Oleh karena itu, guru perlu memperhatikan kesesuaian antara materi dengan me- dia yang akan digunakan. Salah satu media yang dapat digunakan yaitu multimedia inter- aktif bermuatan game edukasi. Artikel ini akan mengkaji pemanfaatan multimedia inter- aktif bermuatan game edukasi dalam pembelajaran IPA di sekolah dasar, serta analisis faktor-faktor yang memengaruhi penggunaan multimedia interaktif bermuatan game edukasi dalam proses pembelajaran (Wulandari et al., 2016).

Untuk mengetahui sejauh mana perangkat lunak (software) interaktif tersebut dapat diterima oleh siswa, maka dimanfaatkan metode TAM (tecknology acceptance model) untuk mengukurnya.
Menurut (Levie, W. H. and Lentz, 2012) mengemukakan empat fungsi media pembelajaran, khususnya media visual yaitu fungsi atensi, fungsi afektif, fungsi kognitif dan fungsi kompensatoris".

Berdasarkan penelitian terdahulu yang telah dilakukan menggunakan game edukasi berbasis multimedia interaktif hasilnya siswa dapat meningkatkan kreativitas mereka dan lebih efektif sebagai media pembelajaran.

\section{METODE PENELITIAN}

Penelitian ini dilakukan dengan metode experimen yaitu setiap siswa menggunakan Komputer yang sudah terinstall aplikasi berhitung, kemudian siswa menjalankan apliksi berhitung dan menginput nama, selanjutnya memilih menu seperti berlatih, bermain dan terakhir mengerjakan soal-soal yang dibatasi oleh waktu. Metode pembelajaran dilakukan oleh guru dengan langkahlangkah sebagai berikut:

1. Menerangkan yaitu guru menjelaskan materi yang akan diajarkan.

2. Mendemontrasikan yaitu guru mendemontrasikan aplikasi berhitung yang digunakan.

3. Praktek yaitu setiap siswa praktek langsung menggunakan aplikasi berhitung di komputer masing-masing.

"Sudjana dan Rivai mengemukakan manfaat media pembelajaran berbasis multimedia dalam proses belajar siswa, diantaranya:

1. Pembelajaran akan lebih menarik perhatian siswa.

2. Metode pembelajaran akan lebih bervariasi.

3. Serta siswa dapat lebih banyak melakukan kegiatan belajar (praktek).

Pembelajaran visual merupakan metode belajar dengan menggunakan teks, gambar, diagram, suara, dan animasi, yang memberikan kemudahan siswa dalam menyerap informasi yang bertumpu pada penglihatan.

\section{Pengumpulan Data}

Data yang diperoleh dalam penelitian ini ada dua yaitu:

1. Didasarkan pada nilai yang diperoleh oleh siswa dengan memperhatikan nilai Kriteria Ketuntasan Minimal (KKM). Sebagai ketentuan yang diberikan untuk mengetahui apakan proses pembelajaran yang dilakukan 
sudah memenuhi setandar minimal, maka setiap mata pelajaran menentukan KKM yang berbeda-beda, Untuk tempat penelitian ini dilakukan di SD BHK Cibubur menentukan KKM untuk pelajaran komputer yaitu nilai 70 untuk skala 100 dan nilai 7 untuk skala 10 . Pengumpulan data dilakukan dengan langkahlangkah berikut:

a. Observasi

Datang langsung ke Sekolah Dasar menginstall perangkat lunak ke computer yang ada.

b. Mencatat nilai hasil praktek

Setiap siswa mengerjakan soal-soal yang ada dalam perangkat lunak belajar berhitung, kemudian hasilnya di catat.

2. Studi Pusataka

Membaca buku-buku yang berkaitan dengan teknologi pembelajaran berbasisi multimedia.

3. Menyebarkan kuesioner ke 33 siswa dengan pertanyaan bagaimana penerimaan siswa terhadap penggunaan media pembelajaran dengan ketentuan sbb:

Tabel 1. Skor Jawaban

\begin{tabular}{lc}
\hline \multicolumn{1}{c}{ Jawaban Responden } & Skor \\
\hline Sangat setuju & 4 \\
\hline Setuju & 3 \\
\hline Kurang setuju & 2 \\
\hline Tidak setuju & 1 \\
\hline \multicolumn{2}{c}{ Sumber : (I Ketut Sudaryana dan Rouly } \\
\multicolumn{2}{c}{ Doharma, 2019) }
\end{tabular}

Langkah berikutnya menentukan skor ideal dengan rumus:

Skor kriterium $=$ nilai skala $\mathrm{X}$ jml

Tabel 2. Skor Ideal

\begin{tabular}{cc}
\hline rumus & Skala \\
\hline $4 \times 33=132$ & $\mathrm{SS}$ \\
\hline $3 \times 33=99$ & $\mathrm{~S}$ \\
\hline $2 \times 33=66$ & $\mathrm{KS}$ \\
\hline 1 X 33 $=33$ & $\mathrm{TS}$ \\
\hline $\begin{array}{c}\text { Sumber : (I Ketut Sudaryana dan Rouly } \\
\text { Doharma, 2019) }\end{array}$
\end{tabular}

\section{HASIL DAN PEMBAHASAN}

\section{Model Games}

Games pembagian di install ke komputer, kemudian guru mengajarkan dan menjelaskan cara mengoperasikan software pembagian dan bagaimana cara menyelesaikan soal-soal, mengisikan skore atau nilai yang diperoleh dan mengakhiri proses pembelajaran.

Metode pembelajaran yang digunakan ceramah tentang pembagian, kemudian mendemokan software pembagian, terakhir praktek atau eksperimen untuk mendapatkan nilai yang nantinya menjadi nilai raport.

Tampilan game pembagian sebagai berikut:

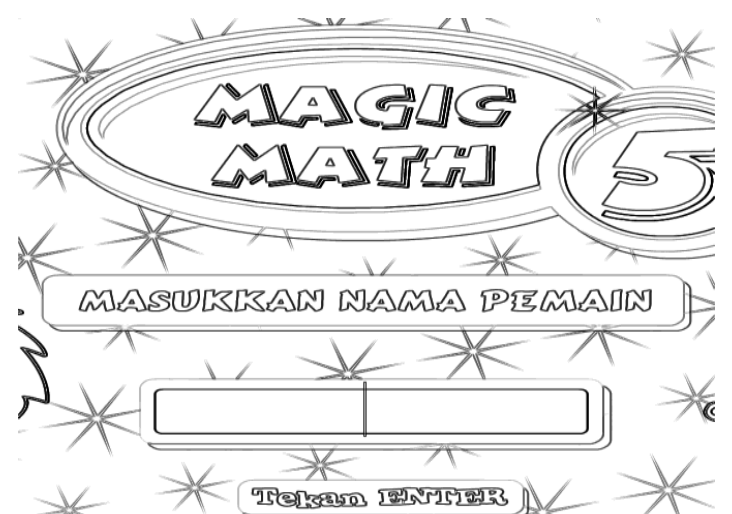

Sumber : (I Ketut Sudaryana dan Rouly Doharma, 2019)

Gambar 1. Menu untuk input nama siswa

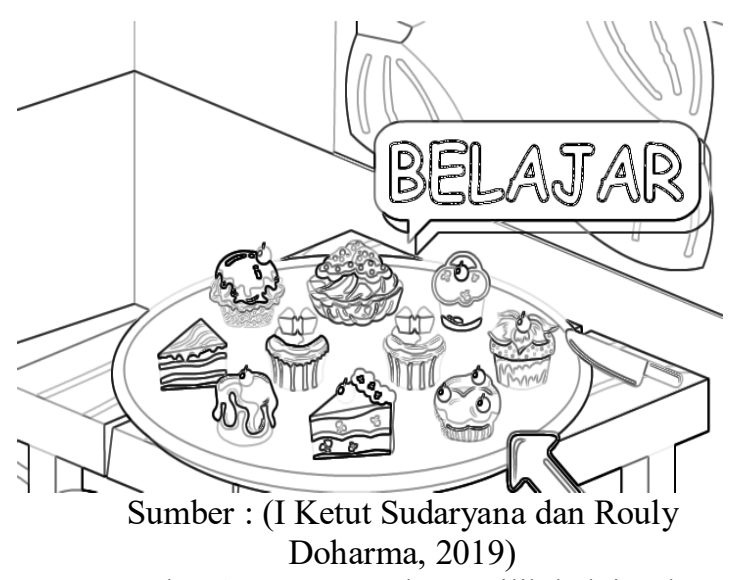

Gambar 2. Menu untuk memilih belajar dan main game.
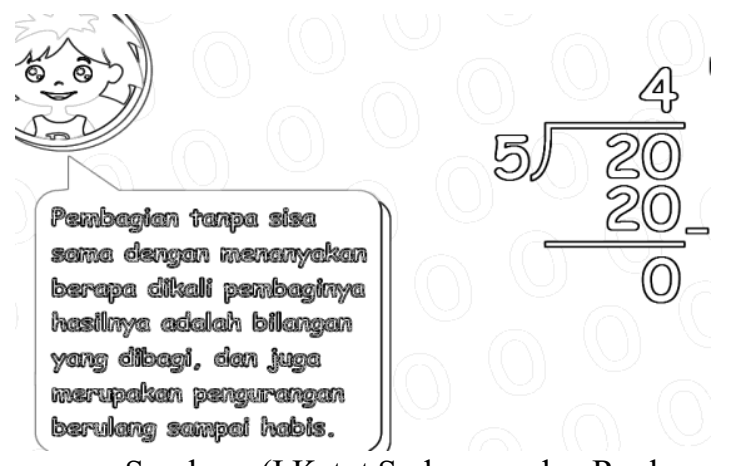

Sumber : (I Ketut Sudaryana dan Rouly Doharma, 2019)

Gambar 3. Contoh ketika memilih menu belajar 


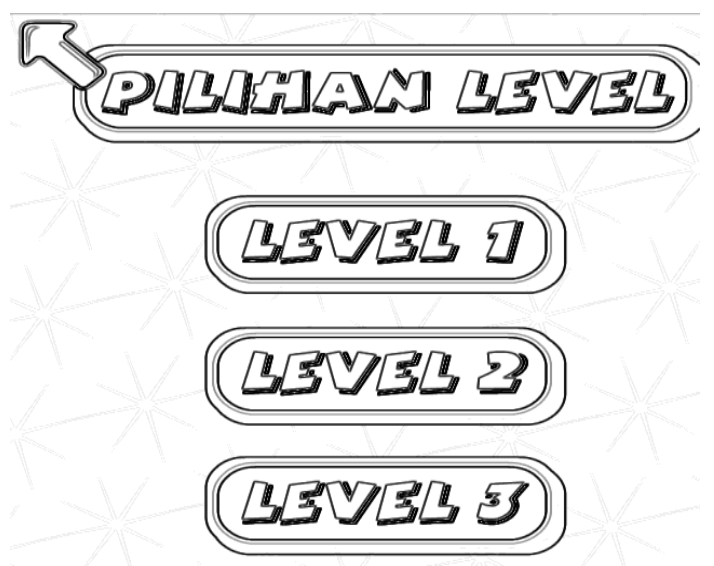

Sumber : (I Ketut Sudaryana dan Rouly Doharma, 2019)

Gambar 4. Ketika memilih menu game, muncul level permainan.

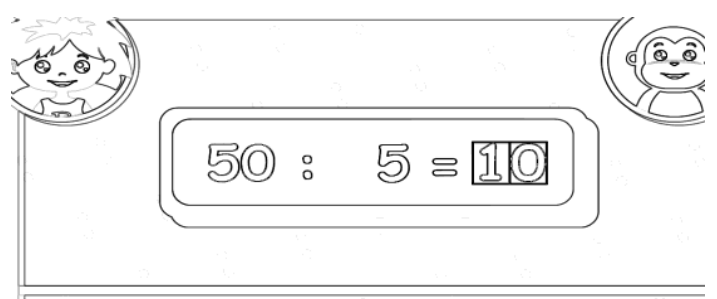

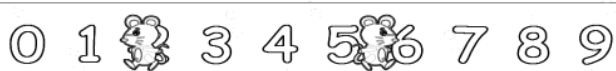
Sumber : (I Ketut Sudaryana dan Rouly Doharma, 2019)

Gambar 5. Contoh soal yang harus diselesaikan oleh siswa.

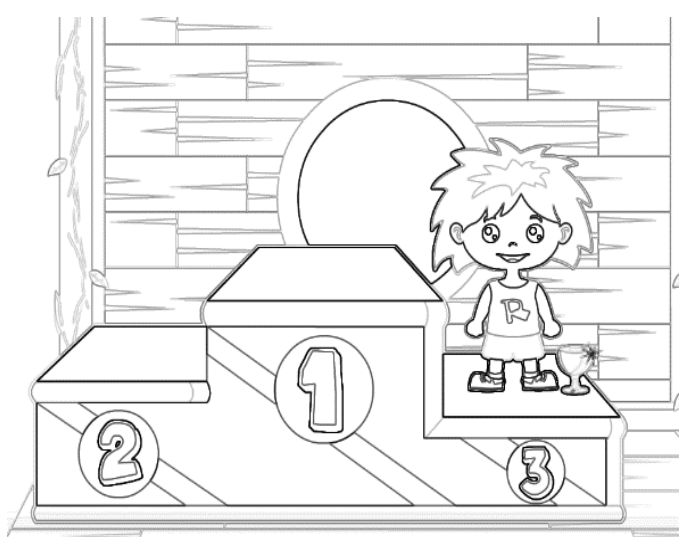

Sumber : (I Ketut Sudaryana dan Rouly Doharma, 2019)

Gambar 6. Diakhir permainan setiap siswa akan mendapatkan nilai yang ditentukan oleh waktu dan benar dalam menjawab soal.

\section{Implementasi}

Dari hasil implementasi kepada kelas 5 dengan jumlah siswa 33 orang di peroleh nilai dari masingmasing siswa sebagai berikut:
Table 3. Nilai

\begin{tabular}{llllllll}
\hline 85 & 80 & 90 & 90 & 70 & 90 & 85 & 90 \\
\hline 60 & 85 & 80 & 75 & 90 & 85 & 90 & 90 \\
\hline 85 & 90 & 90 & 70 & 90 & 70 & 90 & 90 \\
\hline 85 & 85 & 90 & 85 & 90 & 90 & 90 & 90 \\
\hline 85 & \multicolumn{1}{c}{} \\
\hline \multicolumn{1}{c}{ Sumber : (I Ketut Sudaryana dan Rouly } \\
Doharma, 2019)
\end{tabular}

Pembahasan dari hasil nilai yang diperoleh, sebagai berikut:

Jumlah nilai siswa di atas KKM

$$
32 / 33 * 100 \% \quad=0.97
$$

Jumlah nilai siswa di bawah KKM

$$
1 / 33 * 100 \% \quad=0.03
$$

Hasil kuesioner dari 33 siswa dengan pertanyaan "bagaimana media pembelajaran dapat diterima sebagai sarana untuk meningkatkan kemampuan anak dalam belajar berhitung hasilnya sebagai berikut:

Table 4. hasil kuesioner

\begin{tabular}{cc}
\hline Jawaban & Jumlah Siswa \\
\hline SS & 7 \\
\hline S & 21 \\
\hline KS & 5 \\
\hline TS & 0
\end{tabular}

Sumber : (I Ketut Sudaryana dan Rouly Doharma, 2019)

Untuk menghitung prosentase menggunakan rumus: $\mathrm{p}=\mathrm{f} / \mathrm{n} \times 100 \%$

$$
\begin{gathered}
\mathrm{P}=21 / 33 \times 100 \% \\
\mathrm{P}=64 \%
\end{gathered}
$$

Tabel 5. Prosentase skor

\begin{tabular}{cc}
\hline Presentase & Skor \\
\hline $75 \%<$ presentase $<100 \%$ & $\mathrm{SS}$ \\
\hline $50 \%$ <prosentase $<75 \%$ & $\mathrm{~S}$ \\
\hline $25 \%<$ prosentase $<50 \%$ & $\mathrm{KS}$ \\
\hline $0 \%$ <prosentase $<25 \%$ & $\mathrm{TS}$ \\
\hline \multicolumn{2}{c}{ Sumber : (I Ketut Sudaryana dan Rouly } \\
Doharma, 2019)
\end{tabular}


Dengan demikian $64 \%$ berada pada skor setuju, yang artinya media pembelajaran dapat diterima.

\section{KESIMPULAN}

Dari dua data yang diolah berdasarkan Kriteria Ketuntasan Minimal (KKM) yang prosentasenya berada pada $97 \%$ dan hasil dari Kuesioner berada pada hasil $64 \%$, maka dapat disimpulkan bahwa:

Games belajar berhitung untu kelas 5 dapat membantu siswa dalam belajar berhitung khususnya pembagian. Dan media pembelajaran dapat diterima sebagai alat bantu untuk memahami materi ajar di sekolah.

\section{DAFTAR PUSTAKA}

Arsyad, A. (2009). Media Pembelajaran. Raja Grafindo Persada.

Dony Novaliendry. (2013). Aplikasi Game Geografi Berbasis Multimedia Interaktif ( Studi Kasus Siswa Kelas IX SMPN 1 RAO ). Jurnal Teknologi Dan Pendidikan, 6(2), 106-118.

I Ketut Sudaryana dan Rouly Doharma. (2019). Game Simulasi Belajar Pembagian Berbasis Multimedia Untuk Anak Kelas 5. In Infotech: Journal of Technology Information (Vol. 4, Issue 2).

Kuswardayan,I, Nikensasi, P, S. (2012). Rancang Bangun Permainan Edukasi Matematika dan Fisika dengan Memanfaatkan Accelerometer dan Physics Engine Box2d pada Android. ITS, 255-260.

Levie, W. H. and Lentz, R. (2012). Effects of text illustrations. Educational Communication and Technology Journal, 30, 195-232.

Wulandari, R., Susilo, H., \& Kuswandi, D. (2016). Multimedia Interaktif Bermuatan Game Edukasi Sebagai Salah Satu Alternatif Pembelajaran Ipa Di Sekolah Dasar. Jurnal Pendidikan, 1-8. 
